\title{
Creative Adaptive Criminal Entrepreneurs from Africa and Human Trafficking in Belgium: Case Studies of Traffickers from Nigeria and Morocco
}

\author{
Johan Leman* and Stef Janssens
}

KU Leuven, Leuven, Belgium

\begin{abstract}
The article is based on 48 Belgian judicial files (27 Nigerian and 21 Moroccan ones), that concern the practices that created victims of human trafficking from Nigeria and Morocco in Belgium and some neighbouring countries. We discover that the most efficient criminal entrepreneurs are the very flexible ones, who continuously adapt, learn, dare to diversify, and sometimes also to internationalize (but mostly with African partners). An important difference with the Eastern European criminals whom we studied in former research, is that the Africans most of the time do not look for coverage of their practices through legal firms. Their learning practice remains re-active; until 2012 it does not really become pro-active. There is no pro-active longer term vision and no intention to create legal structures that hide their praxis.
\end{abstract}

Keywords: Criminal entrepreneurship, human trafficking, learning, Africa.

In a recent report of the U.N. one may read:

"About 18 per cent of the total number of victims detected in Western and Central Europe are African. Victims from West Africa, especially but not only Nigerians, comprise the vast majority. West Africans accounted for about 14 per cent of the total number of victims detected here, and they were reported by 20 countries of Western and Central Europe. West Africans were detected in the Scandinavian countries, Austria, Belgium, France, Germany, Greece, Ireland, Italy, the Netherlands, Spain, the United Kingdom and other countries... Nigerian victims were detected in 16 countries in Western and Central Europe... With respect to victims from North Africa, Moroccan victims were detected in nine countries in West and Central Europe, including Belgium, France, Italy, the Netherlands and Spain" (UNODC, 2012).

\section{REPRESENTATIVENESS OF THE CASES}

In Belgium and its neighbouring countries, human trafficking $(=\mathrm{HT})$ networks from Nigeria and Morocco are regarded as the most important African networks. It does not mean that they are the most important networks in general in these countries, but they are

*Address correspondence to this author at the KU Leuven, Social Sciences, Parkstraat 45, B-3000 Leuven, Belgium; Tel: 32.(0)16.323598;

Fax: 32.(0)2.411.04.39; E-mail: johan.leman@soc.kuleuven.be when we look at networks originating in the African continent. The CEOOR, the Belgian 'de facto' HT rapporteur, writes that in 2011 a total of 133 victims of HT have been received in the three specialized victims reception centres of the country. Among them the most important group were Moroccan victims (25). In fifth place we find Nigerian victims (8) (CEOOR 2012). In detail, for the reception centres: HT, in general: of 133 victims, 37 have been sexually exploited, 89 economically, and 7 other. For the Moroccans among them: of 25 victims, 1 (woman) sexually exploited, 24 economically (19 men, 5 women). For the Nigerians: of 8 victims, all are women and sexually exploited. The other most represented categories are Romanians: of 22 victims, 3 sexually (women) and 15 economically exploited (2 women and 13 men) and 4 other; Bulgarians, of 11 victims: 6 sexually (women), 5 economically exploited (1 woman and 4 men); Indians, of 10 victims: all economically exploited (1 woman and 9 men). Together they form already 76 of the 133 victims. The remaining 57 victims are categorized in 33 other nationalities. 'Other' as a categorization in our figures, different from sexual and economic exploitation, stands for 'coercion to commit a crime or offence'.

We could study 48 files, among which 27 are Nigerian files and 21 Moroccan ones. Of the 27 Nigerian files, 26 concern exploitation through sex work and 1 exploitation through domestic work by a minor. This profile is similar to the profile of the Nigerian victims in the reception centres. We could also study 21 Moroccan files among which 5 with victims of minor age. Nine files concern sexual exploitation. The profile in our judicial files about Moroccan criminal HT 
entrepreneurs is a bit different from the profile of the Moroccan victims in the reception centres, where victims of sexual exploitation are underrepresented.

\section{DEFINITIONS}

Our definition of $\mathrm{HT}$ is based on the definition given by the Belgian law which is very much conform the definition given by the UN Protocol. UN defines HT basically as bringing over human beings from one country to another for 'sexual exploitation, forced labour or services, slavery or practices similar to slavery, servitude or the removal of organs' (UN 2000a: 3). The Belgian HT law describes exploitation explicitly as: exploitation of prostitution, exploitation of begging, employment in conditions incompatible with human dignity, the removal of organs, and coercion to commit a crime or offence. In our cases, the 'coercion to commit a crime or offence' is related at forced drugs trafficking.

A second definition concerns 'calculating entrepreneurship'. The entrepreneurship model emphasizes the similarities to legal firms (the image of 'the calculating criminal entrepreneur').

In the calculating entrepreneurship model, the criminal entrepreneur is seen as focussing on maximizing profit and treating the trafficked and smuggled customers as commercial goods (Block 1991).

A last question is what we mean with a 'learning process' inside our business concept? We will apply a distinction that is proposed by the theory on the learning organization. It has its origins in organizational psychology but it has been applied in criminology to the Colombian drug cartels (Kenney 1999) and to prostitution networks (Leman and Janssens 2008). One distinguishes two different levels of learning (Kenney 1999). A first lower primary level of re-adaptive learning lies in the domain of the direct reactive reflexes that follow sudden changes within the environment, like for example, those that follow police activities. A second higher level of learning, however, is a proactive one. At this second level, some far-reaching structural changes occur.

\section{QUESTIONS OF INTEREST}

Our research material consists of 27 Nigerian and 21 Moroccan judicial files from 1986 up to 2009, that were examined. Some files have been referred to in the yearly reports of the CEOOR, Belgium's national rapporteur on $\mathrm{HT}$, and a centre that in some cases may have access to the files. Neske and Doomernik (2006:46; see also Pastore et al. 2006:99) write that in their view "court cases are the most reliable source for working out organizational principles of human smuggling", and they certainly are in the case of human trafficking. The question we ask ourselves is, what is the most significant characteristic of these files? And also, what is typically lacking when we compare them with Eastern European files on HT, which are the other important category of HT in Western Europe? We will discover that learning processes, and a huge flexibility in the business that follows from it, are a typical feature of these networks (-for our understanding of networks, see Klerks 2001; Mclllwain 1999). African criminal HT entrepreneurs draw conclusions from past experiences and continuously adapt their entrepreneurship and the manner in which they organize it to changing circumstances.

A second question is: do African criminal HT entrepreneurs not only adapt and change their practices, but also look for structures and firms that hide their activities better, a practice that is quite common in East-European HT and MS (= migrant smuggling)? Our findings will show that most of the time they do not invest in legal constructions such as firms to hide their practices. It means that their learning is fundamentally re-adaptive, not pro-active. We will, however, find one important exception, a case where an entrepreneur entered in contact and collaborated with East-European traffickers.

Our research is an anthropological one. We try to understand from the inside in which way the criminal entrepreneurs are planning their business. It is not a reduction to some overall characteristics that interests us. Our major interest concerns the better developed ways of doing business among them, that show at the same time the dynamics present in the other files.

Let us explicitly state at the end of this introduction, that we absolutely do not wish to use the designations 'Nigerian' and 'Moroccan' here as if our findings will relate to ethnic characteristics that can typify a population group as such, just as we do not do so when using designations as 'Russian' or 'Bulgarian'. We see these designations only as references to a region of origin, whereby some historical factors may play a role in the way these criminal businessmen plan their activities. 


\section{THEORY}

Since from a first reading of the 48 files, the flexible adaptation of these entrepreneurs to the changing environment seemed to us to be one of the most striking characteristics, we privileged two approaches for an understanding: a calculating entrepreneurship model and a psychological theory about how a 'learning organisation' works. From this double perspective, we then scrutinized a second time the changes in the recruitment methods and in the exploitation modalities. We discovered that the 'learning' process never fundamentally questioned the frame in which the business was programmed at the beginning, i.e. when the business was started up. Until 2013, out of 48 files, only in one case the business repositioned itself in a new frame, meaning that in that exceptional case the entrepreneur started working with legal firms. This was the case of an entrepreneur who had East-Europeans as partners. The changes in most of our African files remained changes where an entrepreneur made himself untouchable for the Belgian police escaping to the country of provenance, and from then on using intermediate accomplices in Europe, but without changing the structure itself of the business.

What about our double perspective? In the criminological literature, in the entrepreneurship model the perpetrators are regarded as normal entrepreneurs striving to make a profit where their activities are based on economic market principles (Block 1991). From the East-European criminal HT and MS entrepreneurship practices, we may learn that the entrepreneurs make use of the existing modern management techniques of multinational companies and their branches that operate as business units. They become specialised and function on the basis of subcontracting patterns and flexible collaborative links. When doing so, they may make use of infrastructures such as companies. We can regard this as the control modalities of the criminal network. This is typical nowadays for Russian and Bulgarian criminal entrepreneurs involved in human trafficking (- see Aronowitz 2009; OSCE 2010; Leman and Janssens 2006, 2007, 2008; Shelley 2003, $2004,2010)$. They also may learn to neutralize as much as possible the criminal aspects in their business (cf, 'neutralization theory', see Cullen and Agnew 2003; Sykes and Matza 1957). From a perspective of 'learning organization', we call this a pro-active learning process.

Among African criminal entrepreneurs, we see that they also want to make their business survive. They adapt to the changing circumstances. They draw lessons from their errors from the past. They adapt by using intermediate accomplices in Europe. The entrepreneurs themselves go back to Africa. In the Eastern European case, the criminal networks set up structures to cover up their role in the context of exploitation of human trafficking. Through such constructions the direct link between the co-ordinators of the business and the prostitution facts becomes interrupted. After such structural interventions, the sex workers or the illegally resident workers may for example appear to be working autonomously for themselves. Because of this, it becomes much more difficult for the detectives and the prosecutors to substantiate the evidence for human trafficking. This is not what happens in the African case. There, all perpetrators and accomplices remain equally involved in HT. The difference is that some chiefs can simply remain invulnerable since they do not stay in Europe. In the African approach, however, the facts remain facts of $\mathrm{HT}$ and MS, without possible contestation. It is probable that the different developments between African and East-European criminal entrepreneurs is due to the fact that an increase in intra-European cooperation forces Eastern European criminal entrepreneurs to use more sophisticated, second level learning techniques than the African ones must use.

\section{FINDINGS IN GENERAL}

Among our 27 Nigerian files, 26 women are victims of sex work. In one case there is exploitation through domestic work by a minor. In 10 prostitution files there was also a victim of minor age at work. The age of most of the defendants is between 30 and 40 years old. In only 3 of these files the court acquitted a defendant. In the sex work files there is always a Nigerian 'madam' in a key role. In 9 Nigerian files there are 10 or more defendants. The court judges in such cases that there is a criminal organization at work. It concerns flexible international networks that are active in Belgium, the Netherlands, Italy and Germany. Most defendants and chief defendants are Nigerians. Their accomplices come from Liberia, Sudan, Ghana, Sierra Leone, Togo and Belgium. In most cases there are some 10 victims coming from Nigeria but also from other West-African countries. In 5 files it concerns 5 or 6 defendants, mostly coming from Nigeria, but also from Liberia, Sudan, Ghana and Belgium. In 6 files there are 3 or 4 defendants. In 2 files only 2 defendants. In 5 files we find only one defendant, always one 'madam'. In such files the accomplices from Nigeria and elsewhere in Africa, who were responsible for recruitment and 
repression vis-à-vis family members of the victims there, are not prosecuted. What are the methods of coercion? In 18 files it is debt bondage, meaning that the victims should pay through doing sex work an amount of between 25,000 and 50,000 dollars to get their freedom. In 16 files we see abuse by 'juju' (or voodoo) rituals to control the victim and in 14 files physical violence is also used. Over the years we see files where only a 'madam' or accomplices that stay in Belgium, and not the chiefs or accomplices and defendants who have remained in the country of provenance, are prosecuted, precisely because of the absence of the latter ones.

In our Moroccan cases, there are 5 victims of minor age. In 2 files the court acquitted the defendants. In most cases the defendants are between 25 and 40 years old, more or less as among Nigerians. In 9 files it concerns sexual exploitation, in 9 other files economic exploitation, of which 5 cases of domestic work, 3 of work in a bakery, and 1 in a restaurant. In 3 files, we see how victims are forced to commit criminal acts in the drugs sector, a fact that is absent among Moroccan victims in the reception centres. In 5 files, among which the 3 drugs files and 2 sex work files, more than 5 of the defendants come from Morocco and/or Algeria. In the other files only 1 or 2 Moroccan defendants are concerned, sometimes both a Belgian and a Moroccan one. What are the methods of coercion? In 15 files there is a clear use of physical violence. In 5 files, the perpetrator confiscated the identity papers of the victim so that she could not longer move freely. Over the years we do not see a clear development of the entrepreneurship in the files: physical violence remains quite a common practice and the organization of the business very frequently remains situated in a go between context between Europe and Morocco.

\section{CASE STUDIES CORRESPONDING TO THE PROFILES}

\section{A Nigerian 'Madam' Sex Work File About Facts in 1997-98}

It concerns a file of sexual exploitation in 1997-1998 with 5 Nigerian defendants of age 30 till 40. The principal defendant, Odette (a pseudonym), is a 35year-old Nigerian 'madam'. The defendants used an import - export firm in Italy and Germany and sold the sex workers in Italy. At one of the defendants' home the police found member cards of a Nigerian political party. The provenance of the 13 sex workers, with false Liberian identity papers, was Nigeria and Sudan. To get their freedom the victims had to do sex work. Their so-called debt was 30,000 US dollars for each. The defendants used physical violence.

\section{A Nigerian 'Physical Violence' Sex Work File About Facts in 2000-2002}

Two Nigerian victims complained for HT in a prostitution parlour file in Liège. A businessman recruited them in Nigeria. The contract was made through a voodoo ritual. With the help of an Antwerp solicitor, who has been condemned in the meantime, they had to apply for asylum in Belgium under a false Sudanese identity. They entered in prostitution in Antwerp and later in prostitution parlours in Liège. A third victim that had complained, had also worked in in the prostitution district at the Brussels' North Station. Half of the benefits was for the manager and half for the Nigerian 'madam'. The 'madam' claimed a 50,000 dollar debt they should pay for their stay, false documents and the organization of their activities. If the benefits were not high enough they were beaten by the 'madam'. A brother of one of the defendants menaced their family in Nigeria if they should collaborate with the police in Belgium. The victims refused participation with the police when confronted with pictures of the 'madam'. All victims enjoyed an officially recognized victim status.

In 2010, years later, one of these victims declared: "Since I continued to collaborate with your services, my family got menaced in Nigeria. The reasons are the declarations of my partners. To protect my family, I have no other choice than to refuse each new collaboration with the Belgian police. I also refuse each confrontation with the other victims. I know that I may feel protected in Belgium, but you can do nothing in Nigeria. The families of some perpetrators are very powerful and rich in Nigeria. My family is poor. I don't want problems anymore for them there in Nigeria."

\section{A Moroccan 'Economic Exploitation' File About Facts in 1992-99}

There is only one defendant, a Moroccan man of age 35 . The victims are 3 Moroccan women living together with that man. He maltreated them physically and menaced them even with killing them. The man had seduced them sexually and in this way created their dependency on him. Once they lived with him, he forced them to work in his snack bar without paying them. The man was condemned for HT. 


\section{A Moroccan 'Sex And Domestic Work' File About Facts in 2004}

A solicitor travelled with a Moroccan friend to a very poor area in Morocco to recruit a minor girl for Belgium. The Moroccan man was known by the police for trafficking in drugs, arms and for use of violence. The solicitor chose a 14-year-old virgin girl and gave 2,000 euro to the very poor family. The Moroccan friend brought her to Belgium, where she stayed with the solicitor and his mother. He violated her and she was object of maltreatment by him and his mother. During sexual abuse, the solicitor filmed the scenes. The girl worked also as a domestic worker. solicitor

She had no papers and could not leave the house. After some months the solicitor dumped her and the girl was left alone in the streets. He asked his Moroccan friend to find a new girl. The first victim ended up in psychiatric care and died in a traffic incident. After a procedure of 6 years, the court condemned the solicitor.

\section{A Moroccan 'Sex- Drugs- Marriage of Convenience' File About Facts in 2006-2009}

A Belgian Moroccan female bar keeper, a former sex worker, in Alost (a city in the Flemish part of Belgium, near Brussels), exploited sexually various Moroccan and Brazilian young women, among whom a minor, from 2006 till 2009. The defendant was also involved in drugs trafficking and organization of marriages of convenience. Step by step she brought her victims to prostitution. In Morocco, the victims received a proposition to work as a domestic worker or in a restaurant in Belgium. The bar keeper also contacted undocumented girls in Belgium with such propositions. Most of the time they did not know that sex work was part of the job. In the bar they learned to drink alcohol and to use drugs, step by step. At that moment they were told that sex work could solve their financial problems and that a marriage of convenience would help them to get the needed papers. Various victims made the step. The court condemned the Moroccan bar keeper for HT.

\section{NIGERIAN NETWORKS, GENERAL COMMENT}

About $92 \%$ of Nigerians trafficked to Europe for prostitution come from Edo State of Nigeria. Initially, most came from Benin City, the capital of Edo State (Unesco 2006). The Nigerian networks are well organized (Unesco 2006; Dave-Odigie 2008; State Department 2012). In our files we see that the use of violence as a means of control is endemic. More than often the criminal businessmen also operate internationally and regard corruption as a suitable means of achieving a goal. They remain in contact with their clan in Nigeria, where we see a pyramid structure under the command of clan chiefs. The criminal core business in these Nigerian files is prostitution and trafficking in women, often combined with people smuggling and setting up marriages of convenience. The victims are regarded as commercial goods. Their passport is confiscated. To buy their liberty the sex workers have to pay off sums ranging from 25,000 euro to sometimes 50,000 euro. Violence is not shunned nor are threats to the people left behind at home if the victims do not meet the requirements of the businessmen. In one file, we see how the human traffickers in Nigeria have hired young mercenaries to do the dirty work: houses are set on fire, the parents are beaten up. Each mercenary gets paid 10,000 euro per month (CEOOR 2010).

A typically Nigerian means of repression with respect to the victims is the misuse of a voodoo or 'juju' ritual (Carling 2006, Okojie 2009, Kara 2009, DaveOdigie 2008; State Department, 2012; Aronowitz 2009). Many Nigerian women, before they left for Europe, have taken an oath, before a local 'juju' priest, in which they or their family are bound to pay their travel costs and debts to their 'madam'. Taking this oath is accompanied by a number of rituals (van Dijk et al. 2003; Prina 2003). If the victim does not meet the obligations imposed on her or violates them, 'juju' will be applied. In such case, someone can be made ill or turned crazy or even made to die with a little parcel of nails, blood and hair. This is strong belief. In this way the 'madams', later in the country of destination, can engender fear and anxiety in the girls and create a bond that they cannot violate with impunity before they have paid off their debts (OSCE 2010; Aronowitz 2009; Unesco 2006). Over the years and until now, this kind of practices have remained intact in the country of provenance.

What may change, is the practices in the country of destination. Nowadays, the control of the girls from Nigeria most of the time is in hands of a 'madam' (Carling 2006; OSCE 2010; Aronowitz 2009). This was already the case in our file of 1997-1998. The 'madam', herself a Nigerian, is a person who knows the prostitution system. Generally she herself has worked as a prostitute and she is someone who has bought her liberty (Kreutzer 2008). In our files we see that this system has become generally practiced, with as only 
change that the 'madams' have got higher status and the businessmen themselves do not longer intervene directly in the world of prostitution. In business terms the introduction of the 'madam' to the system is a fine example of how sex work entrepreneurs have learned how to get new sex workers into prostitution without compromising themselves and how to generate maximum profits at no risk to themselves, without this scope to create a legal company structure. It remained limited to a simple, creative but efficient intervention. The traditional 'juju' and violence pressures in Nigeria have remained. Some small adaptation in Belgium by using more exclusively 'madams' as intermediate persons was enough to survive as a business.

In a judicial file we see a police report of 2010 that sketches the following profile of a Nigerian victim in Belgium in 2010. She is generally a 21-year-old woman from Benin City who comes from a large family with a low income. She has had little education and has either no or only scant work experience. Usually the woman knows that she will be working as a prostitute. In some instances the victim is promised a job as a waitress, babysitter or domestic servant. Generally several victims travel together and are accompanied by constantly changing chaperones through several African and European countries before they arrive in Belgium. The journey sometimes takes months and goes via the desert and/or hazardous small boats across the sea. Frequently they have to earn money by working as prostitutes on the journey in Africa to pay for their travel. When they fall ill they are abandoned along the way. According to estimates half of the girls are picked up 'en route' and returned to Nigeria. On arrival in Belgium the victim is eventually transferred to the 'madam', leader of the network here in Belgium, who puts her to work as a prostitute or sells her on. The victim gets the standard story that she has made many debts on the journey and generally accepts this without any form of coercion. It then takes her many years to repay this without her being able to keep some money herself to send to the family. Some of the women hope, once they have repaid the debts, to be able to work themselves as a 'madam' and to then be able to lead a prosperous life in Europe.

In Belgium, the Nigerian HT trade end 2012 is characterised by female leadership at the intermediate levels and principally in the country of destination. Some of the victims 'reproduce' the traditional existing structure once they got liberty after having paid their 'debts' (OSCE 2010; Kreutzer 2008). The chief businessmen remain in Nigeria and remain completely out of sight for the European courts.

\section{NIGERIAN NETWORKS, ORIGIN, DEVELOPMENTS AND ADAPTIVE LEARNING}

From a Unesco report, we learn about factors that help to explain the origin and developments of Nigerian sex work in Western Europe:

"Italy, Belgium, Spain, the Netherlands, Germany and the United Kingdom are the main European destinations. Why Italy? One of the factors could be traced to the historical business transactions between some of the natives from Edo State with Italians when the Nigerian economy was more robust. These Nigerians visited Italy to buy gold, shoes and clothing to sell in Nigeria. When the Nigerian economy began to dwindle, some of these businessmen and women stayed longer to pick potatoes for quick returns before returning home. As the economic situation in Nigeria worsened and the business of picking potatoes was taken over by immigrants from Eastern Europe, the growing sex industry became more lucrative for Nigerian women. Naturally, those Nigerians from Edo State started human trafficking activities using their relatives, friends and community members as commodities. Human trafficking being a clandestine criminal activity, the gang members feel safer recruiting from trusted family members. This could explain why to date over $80 \%$ of trafficked persons for prostitution to Europe, especially Italy, are from Edo State where the trend started" (Unesco 2006).

From a police report in a Belgian judicial file of 2010, we learn more concretely about the context in which Nigerian HT networks arise:

"When oil extraction started in the 1980s large areas of agricultural ground were destroyed and with that also sources of income for the rural populations. Some women, generally married, found themselves forced to work as sex workers for the workers in the oil industry. In the states of Edo and Delta, where most of the 
female sex workers come from, sex work was not socially accepted. But if a man loses his job and is not able to support his wife, she has to look after herself and her children. Sex work is then a quick way of earning money and men are frequently prepared to tolerate this."

This may explain why human traffickers turn in the first place mainly to women and girls from Benin City in Edo but in the meantime it seems as if they have shifted their attention to the rural areas of this state. Once, also in Europe, Nigerian women had entered in sex work (see the Unesco report of 2006), also women who had worked in Nigeria as prostitutes came to Europe. In Europe itself there was a growing demand for African sex workers. These former Nigerian sex workers became the first 'madams', who themselves had first worked as prostitutes in Nigeria and later also in Europe and have bought their own liberty now in Europe. They, in turn, in agreement with the former businessmen in Nigeria, bring new victims into the world of prostitution. Some of these 'madams' may then return from Italy, Spain, Belgium and the Netherlands with enough money to build a house or in some cases several houses in Nigeria. As a consequence, other less poor women also want to go and work in Europe and some parents even encourage their daughter to do so. The chiefs in Benin City can accept it and even stimulate the process, since they understand that it has become more dangerous for them to remain themselves in Europe to do the dirty job. This has initiated (at the beginning of the 1990s) and later reinforced (at the end of the 1990s) a shift to the 'madam' system. In the logic of the re-active, first level, learning process among Nigerian criminal HT entrepreneurs, one may predict, that if this position of 'madam' may become too risky a position, Nigerian criminal entrepreneurs will go in search for a new simple trick in the countries of destination, working further in Nigeria itself as they already do for the last 10 years.

Are there no exceptions among Nigerians? Among our files, there is one case, besides the smaller case we referred to as the 'madam' sex work file about facts in 1997-98, where it concerns a file with facts that happened between 1986 to 1996 . It concerns a Nigerian network that worked via Amsterdam Schiphol airport and had branches that even reached Italy. The Nigerian victims who failed to buy their liberty within six months through prostitution, were sold on in Germany. To make this more plausible, the accused set up an import-export company as a cover to make trafficking in women possible and to allow money to be transferred easily. He even had a business partner with a similar import-export company in Nuremberg in Germany. He internationalized his business. Here we discover a way of working that shows similarity with an Eastern European approach. However, it seems quite exceptional among Nigerians. From the file we learn that there may have been some contacts between the Nigerian businessman and some East European partners.

In the meantime the Nigerian networks have, as has become clear from recent cases in 2011, also set up international exchange programmes. A Nigerian 'madam' in Belgium can get control of victims in Norway, Sweden and Spain. There also appear to be exchange programmes in which for example a Nigerian 'madam' in Spain sends a girl to Belgium to work for her, but under the supervision of the Nigerian 'madam' in Belgium. Also in a purely re-active learning business dynamics, internationalization of the business is absolutely not excluded.

\section{MOROCCAN NETWORKS, GENERAL COMMENT}

The Moroccan human trafficking networks in Belgium are small-scale networks, usually family linked. They use violence against their victims. In addition some of them may turn up in larger networks but in that case, the Moroccan operatives generally find themselves working in a subordinate position. The Moroccan networks are active in prostitution and principally in economic exploitation and in setting up marriages of convenience. Moreover many Moroccan victims were forced to criminal acts in drugs trafficking. The Trafficking in Persons report of the US State Department has also referred to similar practices (State Department 2012): A few Moroccan men and boys are lured to Europe by fraudulent job offers and are subsequently forced to sell drugs.

This mix of drugs trafficking and HT is quite typical of Moroccan criminal entrepreneurship. It is already characteristic of much HT and MS worldwide (EUROJUST 2008; OSCE 2010; Janssens 2010; Shelley 2010), but from our files we see that more Moroccan than Nigerian traffickers correspond to this profile.

MOROCCAN NETWORKS, ORIGIN, DEVELOPMENTS AND ADAPTIVE LEARNING

Migration from Morocco to Belgium started officially in 1964. With the migration stop of 1973-1974 
everywhere in Western Europe, settlement of immigrants has become a definitive fact. WestEuropean countries have become countries of definitive residence for most of the immigrants. Life with all its complex positive and negative aspects can start developing. Already in the 1980 s we see how Moroccan pimps became active in Belgium on a small scale in prostitution bars where they forced victims into prostitution. In a Moroccan case in Leuven (a city at 30 $\mathrm{km}$ from Brussels) with facts dating from 1985 and running until 1996, in two prostitution bars, there were at least 9 victims. The victims were of various nationalities and had legal residence status. Some victims had previously been working as prostitutes in Morocco. They came to Belgium by means of a marriage of convenience and were pushed into working as prostitutes.

After 2000 we find that there are some refinements in how the Moroccan pimps work. In the case of Mounia (not her true name), a Belgian-Moroccan bar manageress (- for the agency of women as managers, see Agustin 2006), Mounia herself is an ex-prostitute. She sexually exploited from 2006 to 2009 various young Moroccan and Brazilian women, including an underage girl. The accused had also been involved in drug crimes and in setting up marriages of convenience. Based on a calculation of her illegal amassed capital, during the trial a seizure was requested of 2.5 million euro. From this case, we learn that the victims were forced into prostitution in a subtle, step by step manner. In most cases the victims, still living in Morocco, were offered work as domestic servants or as a help in a restaurant in Belgium. Young girls who were illegally resident here and who encountered many problems in finding work, received such a proposal, too. They were generally not informed of the fact that the offer involved prostitution. During a first confrontation with the bar and by using alcohol and drugs, the victims' boundaries were gradually broken down, step by step. At the same moment they were told how all their financial and residence problems could be solved through working as a sex worker. Next the victims received a proposal to enter into a marriage of convenience with the assertion that by doing this they could get residence documents but that for that they had to earn a lot of money through their sex work. Several victims did in fact enter into a marriage of convenience. The accused had a clear preference for victims who were undocumented residents whom she 'could manipulate in her way'. When there were conflicts with the victims, she threatened to call some
Albanians by way of intimidation. One Brazilian victim explained that after a dispute the accused had phoned a Moroccan friend. This person had come to the brothel and said threateningly that he would regard anyone wanting to harm the accused as a personal attack on himself so that he would then have to take the necessary actions. The strategy used by Mounia is quite simple: she uses all the opportunities that the environment offers to exploit people in a vulnerable position.

But, in the 1990s, we see how the Moroccan human traffickers in Belgium started focussing on a new sector, the economic exploitation sector. They discovered the sector of domestic servants, bakers, butchers and the catering sector. They may exploit young women in different existing statuses that can be used in a perverse sense, for example as au-pair girls. In such a situation, a perpetrator can also start having a sexual relationship with the victim to make her dependent. As a result they are culturally no longer of interest for other men. Such a perpetrator can then set such women to work, for example in his snack bar.

After 2000, we also see exploitation emerge among Moroccan men in the construction sector. In a Moroccan file, we see how a Belgian-Moroccan businessman exploited various Moroccan workers in 2008 via his construction company in the region of Brussels and Charleroi (a city in the south of Belgium). Some victims were also exploited in the Netherlands. The victims were approached in Morocco and lured to Belgium with false promises. They found themselves in a situation of debt obligation in which they were compelled to work for a period for free in order to pay off their debts. The accused had specially set up a company in Belgium at the beginning of 2008 to allow workers from Morocco to come to Belgium and to be able to put them to work legally with a work permit B which permits foreigners to work in Belgium for a determinate period. For the price of 6,000 euro the entrepreneur arranged the passports and the work permits for the Moroccan workers. The victims had to pay this in advance to the accused in order to be able to come and work in Belgium. In compensation they could also opt to do renovation work in one of his houses in Morocco before leaving to come to Belgium. The victims were not paid in the end and had to work for free to pay off their so-called debts. According to one victim, the accused made death threats to him and his family. This is not really using a legal firm to hide illegal activities. This is creating a legal firm to organize in the most direct way economic exploitation, hoping 
that it will not be judged as HT but only as working in a grey area, which leads to lower - and normally only financial - penalty (and permits even to escape in time to Morocco). Here again, the learning process consists in an exploitation of legal and bureaucratic procedures in the country of destination, knowing that there are possible escapements for the perpetrator.

In the same period, also another business, namely drugs trafficking, has discovered some opportunities offered by HT and MS. Drugs traffickers may set up constructions in which smuggled victims are coerced into dealing drugs in order to pay off their debts, and are firstly given training for this. In a drugs case dating from 2008 the accused were prosecuted and sentenced in the context of drug dealing. The network recruited Moroccans or Algerians, either in their country of origin or in Spain, to send them to Belgium. Once in Belgium, they had to sell drugs on the street or at 'market houses'.

\section{CONCLUSION}

We see that African criminal HT networks that are developed in the context of calculating entrepreneurship learn from their errors and adapt after a judicial action, in the same way as they also adapt in a creative manner to government measures. But most of the time, they do not follow the paths traced by for example their Eastern-European colleagues, who work with firms, agencies, transport companies... It may happen that the Nigerians work with companies, but not to hide the HT or MS activities by cutting the direct link with exploitation, setting up win/win relations, or a 'dames de compagnie' system (what is different from the 'madam' system). The Eastern European 'dames de compagnie' have a status of being independent workers; the Nigerian 'madams' don't have such a status; they remain intermediating persons. The African criminal entrepreneurs don't need to apply the Eastern European 'hiding' second-level structure, since they remain out of reach for the judicial system by staying in the country of provenance. The flexible changes they make are only concerned with changes in the country of destination. One should for example not exclude that in the near future more and more criminal HT networks will try to organize themselves, as already some of the Moroccan criminal businessmen do, in such a way that most of their activities escape the European HT legislations and can be treated as cases only of organized illegal moonlighting. In this sense, African criminal entrepreneurs analyze very well what are possible new needs of some new migrants (irregular ones), in the Moroccan case, or they take in account the changing demands in the European sex work market, in the Nigerian case.

The Moroccan criminal entrepreneurs can try to make the business more remunerative adding other criminal activities to it, and they make it less risky organizing easy mobility between Europe and Morocco. The Nigerian criminal entrepreneurs focus more on recycling former Nigerian sex workers as 'madams', remaining out of sight in Nigeria themselves. It does not exclude that these criminal entrepreneurs try to internationalize their partnerships, but in the Nigerian case the partnerships most of the time are with other African partners (where the Nigerians remain in command), while in the Moroccan case there is less such collaboration and if it happens, the Moroccans remain in the weaker position. This is different from what happens among Eastern Europeans, who collaborate more easily with non-European (mostly Asian) colleagues.

The interest of a correct understanding of the differences in the learning processes, where one may discover how Eastern European HT entrepreneurs work differently from Moroccan or Nigerian traffickers, even if they surely may also learn from one another, is, that if we want an adequate suppression policy of a phenomenon that is a huge challenge for the $21^{\text {st }}$ century, we cannot be satisfied with achieving easy successes. It certainly cannot be the intention of a policy to leave the field open to the most professional and most creative of the criminal networks, remaining one step behind to those 'calculating entrepreneurs' that possess the most adequate learning capacity.

\section{ACKNOWLEDGEMENTS}

We thank the two anonymous reviewers for their very precious suggestions.

\section{REFERENCES}

Agustin, Laura 2006. "The Conundrum of Women's Agency: Migrations and the Sex Industry," Pp. 116-140, in Sex Work Now, edited by M. O'Neill, and R. Campbell. Collumpton: Willan Publishing.

Aronowitz, Alexis 2009. Human Trafficking, Human Misery: the Global Trade in Human Beings. Greenwood Publishing Group.

Block, Alan 1991. Perspectives in organizing crime; essays in opposition. Dordrecht: Kluwer Academic Publishers. http://dx.doi.org/10.1007/978-94-011-3344-9

Carling Jorgen 2006. Migration, Human Smuggling and Trafficking from Nigeria to Europe, Geneva: International Organization for Migration. 
CEOOR 2010. Annual report on Trafficking and Smuggling of human beings. (translated from Dutch/French). Combating social fraud to prevent trafficking in human beings. Centre for Equal Opportunities and Opposition to Racism, Brussels.

Cullen, Francis and Robert Agnew 2003. Criminological Theory. Los Angeles: Roxbury Publishing Company.

Eurojust 2008. Annual Report 2007. http://www.eurojust.europa. eu/press_releases/annual_reports/2007/Annual_Report_200 7_EN.pdf The Hague. (note: Eurojust is a judicial cooperation body created to improve the fight against serious crime by facilitating the optimal co-ordination of action for investigations and prosecutions covering the territory of more than one Member State in the European Union).

Kara, Siddarth 2009. Sex Trafficking: Inside the Business of Modern Slaver y. New York: Columbia University Press.

Kreutzer, Mary and Corinna Milborn 2008. Ware Frau. Auf den Spuren moderner Sklaverei von Afrika nach Europa, Econwin, Salzburg.

Janssens, Stef 2010. "Fenomeenanalyse van mensenhandel." Pp. $41 \mathrm{ss}$,in Traite des êtres humains, MensenhandelMensensmokkel. Les dossiers de la rue de droit pénal et de criminologie, eidted by C.E. Clesse. Brussels: La Charte.

Kenney, Michael 1999. "When Criminals Out-smart the State: Understanding the Learning Capacity of Columbian Drug Trafficking Organisation", Transnational Organized Crime, vol. 5, n. 1, Spring: 97-119.

Klerks, Peter 2001. The Network Paradigm Applied to Criminal Organisations. Connections 24, 3:53-65.

Leman, Johan and Stef Janssens 2006. "An Analysis of Some Highly-Structured Networks of Human Smuggling and Trafficking from Albania and Bulgaria to Belgium", Migracijske i etnicke teme, Zagreb, vol. 22, $n^{\circ}$ 3: 231-245.

Leman, Johan and Stef Janssens 2007. "Travel Agencies as a Linking Element for Human Smuggling and Trafficking from Eastern Europe", Studi Emigrazione/Migration Studies, XLIV, n. $166,443-459$.

Leman, Johan and Stef Janssens 2008. "The Albanian and postSoviet business of trafficking women for prostitution: Structural developments and financial modus operandi", European Journal of Criminology, vol. 5, nr. 4: 433-451. http://dx.doi.org/10.1177/1477370808095125

Leman, Johan and Stef Janssens 2010. "Bulgarian human trafficking in Belgium and proactive learning entrepreneurship: developments 2002-2009", Migracijske i etnicke teme, Zagreb, vol. 26, $n^{\circ} 1$ : 7-26.

Mclllwain, Jeffery Scott 1999. "Organized Crime. A Social Network Approach." Crime, Law and Social Change, 32, 301-323. http://dx.doi.org/10.1023/A:1008354713842

Neske, Matthias and Jeroen Doomernik 2006. "Comparing notes: Perspectives on human smuggling in Austria, Germany, Italy, and the Netherlands," International Migration, 44: 9-58.

Norwegian Directorate of Immigration 2004 „Report from a factfinding trip to Nigeria (Abuja, Kaduna and Lagos) 23-28
February 2004", The Norwegian Directorate of Immigration, Oslo.

Okojie, Christiana 2009. "International Trafficking of Women for the Purpose of Sexual Exploitation and Prostitution in the Nigerian Case," Pakistan Journal of Women's Studies, 16(12): 147-178.

OSCE 2010. Analysing the Business Model of Trafficking in Human Beings to Better Prevent the Crime, written by Aronowitz, Alexis, Theuermann, Gerda and Elena Tyurykanova. OSCE/ODIHR

Dave-Odigie, Chinenye 2008. "Human Trafficking Trends in Nigeria and Strategies for Combating the Crime," Peace Studies Journal Vol. 1 Issue 1

Pastore, Ferruccio, Monzini, Paola and Giuseppe Sciortino 2006. "Schengen's soft underbelly? Irregular migration and human smuggling across land and sea borders to Italy", in International Migration, 44: 95-119. http://dx.doi.org/10.1111/j.1468-2435.2006.00381.x

Prina, Franco 2003. "Trade and exploitation of minors and young Nigerian women for prostitution in Italy", United Nations Interregional Crime and Justice Research Institute (UNICRI), Programme of action against trafficking in minors and young women from Nigeria into Italy for the purpose of sexual exploitation., Torino.

Shelley, Louise 2003. "The trade in people in and from the former Soviet Union", in. Crime, Law and Social Change, 40: 231249.

http://dx.doi.org/10.1023/A:1025792806522

Shelley, Louise 2004. "Contemporary Russian Organised crime: Embedded in Russian Society". Pp. 563-584, in Organised Crime in Europe. Concepts, Patterns and Control Policies in the European Union and Beyond, edited by Fijnaut, Cyrille and Letizia Paoli. Dordrecht: Springer,.

Shelley, Louise 2010. Human Trafficking: a Global Perspective. Cambridge University Press. http://dx.doi.org/10.1017/CBO9780511760433

Sykes, Gresham and David Matza 1957. "Techniques of neutralizations: A theory of delinquency," American Sociological Review, 22, 664-670. http://dx.doi.org/10.2307/2089195

UNESCO 2006. Human Trafficking in Nigeria: Root causes and recommendations', policy paper poverty series, Paris http://unesdoc.unesco.org/images/0014/001478/147844e. Pdf

United Nations Office on Drugs and Crime [UNODC] 2012 "Monitoring the Impact of Economic Crisis on Crime", Vienna: UNODC. http://www.unodc.org/documents/data-andanalysis/statistics/crime/GIVAS_Final_Report.pdf

Van Dijk, Rijk, Theo Rasing, Nina Tellegen and Wim van Binsbergen 2003. „Een schijn van Voodoo. Culturele achtergronden van de handel in Nigeriaanse meisjes voor de Nederlandse prostitutie: Een verkenning", African Studies Centre, Universiteit Leiden, Leiden.

\section{DOI: http://dx.doi.org/10.6000/1929-4409.2013.02.15}

(C) 2013 Leman and Janssens; Licensee Lifescience Global.

This is an open access article licensed under the terms of the Creative Commons Attribution Non-Commercial License (http://creativecommons.org/licenses/by-nc/3.0/) which permits unrestricted, non-commercial use, distribution and reproduction in any medium, provided the work is properly cited. 